\title{
Relationship between Files that Bind at the Apical Foramen and Foramen Openings in Maxillary Central Incisors - A SEM Study
}

\author{
Ronaldo Araújo SOUZA ${ }^{1}$ \\ Yara T. Corrêa Silva SOUSA ${ }^{1}$ \\ José Antônio Poli de FIGUEIREDO² \\ João da Costa Pinto DANTAS ${ }^{3}$ \\ Suely COLOMBO ${ }^{3}$ \\ Jesus Djalma PÉCORA ${ }^{4}$ \\ ${ }^{1}$ Graduate Program, Dental School, University of Ribeirão Preto, Ribeirão Preto, SP, Brazil \\ ${ }^{2}$ Graduate Program, PUCRS - Pontifical Catholic University of Rio Grande do Sul, Porto Alegre, RS, Brazil \\ ${ }^{3}$ Graduate Program, Dental School, Bahiana School of Medicine and Public Health, Salvador, BA, Brazil \\ ${ }^{4}$ Department of Restorative Dentistry, Ribeirão Preto Dental School, \\ USP - University of São Paulo, Ribeirão Preto, SP, Brazil
}

\begin{abstract}
Considering that instrumentation of the apical foramen has been suggested for root canal infection control, this study analyzed the relationship between the files that bind at the apical foramen and the foraminal openings in 50 maxillary central incisors. After preparation of the pulp chamber, access to the canal was obtained with \#1 and 2 LA Axxess and K-files with tip cut were inserted up to the apical foramen until binding was felt. The files were fixed with methyl cyanoacrylate and the tooth-file sets were cross-sectioned $10 \mathrm{~mm}$ short of the apex. Scanning electron microscopic analysis was carried out and files and foraminal areas were measured using Image Tool software. Statistically significant difference $(\mathrm{p}<0.0001)$ was found between files and the apical foraminal areas. The mean foraminal area was 3.8 times larger than the mean file area. The results of this study suggest that it would require 4 files of greater size beyond the one that bound to the foramen in order to allow a better relationship between files and apical openings of maxillary central incisors
\end{abstract}

Key Words: Apical foramen, apical patency, infection control, root canal instrumentation.

\section{INTRODUCTION}

Inaccessibility to apical constriction and preoperative presence of periradicular lesion are significant factors related to outcome, increasing the risk of root canal therapy failure (1).

Debridement of the root canal by instrumentation and irrigation is considered the most important single factor in the prevention and treatment of endodontic diseases (2). Instrumentation should go apically enough to eliminate or at least reduce bacterial load (3).

The presence of microorganisms in the cemental canal and their participation in the development of periapical lesions has been well demonstrated $(4,5)$ and therefore this part of the radicular anatomy should not be overlooked during root canal therapy.

Apical patency consists of the passive use of a small size file through the apical constriction without enlarging this region (6). Despite the fears in the past with apical foramen handling (7), this has been recently proposed $(7,8)$.

While some authors $(3,7,9)$ believe that apical patency promotes cleaning of the cemental canal, others $(10,11)$ raised the question of how can this procedure clean properly using an instrument with smaller diameter than that of the apical foramen.

With the understanding that cleaning should involve mechanical action on the walls of the cemental canal, the question of which file could play this role arises. It is possible that an appropriate instrument would 
be the one that binds at the apical foramen.

There is no information on this topic in endodontic literature. The aim of this study was to analyze the relationship between the files that bind at the apical foramen and the apical foramen openings in maxillary central incisors by scanning electron microscopy.

\section{MATERIAL AND METHODS}

Fifty human maxillary central incisors with complete root formation from the tooth bank of the Dental School of the Bahiana School of Medicine and Public Health were used. Inclusion criteria were lack of complex anatomy, acute curves, incomplete root formation and apical resorption, observed by means of direct examination and periapical radiographs. This study was approved by the Ethics Committee of the University of Ribeirão Preto (Protocol \#124/09).

Access and preparation of the pulp chamber were carried out with a \#3 carbide round bur (KG Sorensen, Cotia, SP, Brazil) and Endo-Z bur (Maillefer, Ballaigues, Switzerland). Root canals were explored with a size 15 K-file (MMDF, Burges, France) with watch-winding motion until the tip was visible at the apical foramen and root length was determined at this stage.

Line access was performed with \#1 and 2 LA Axxess (SybronEndo, Glendora, CA, USA), which correspond to 20/.06 and 35/.06 file tips, $4 \mathrm{~mm}$ short of root length with concomitant irrigation with $1 \mathrm{~mL} 2.5 \%$ sodium hypochlorite (Q-Boa; Indústrias Anhembi S/A, Osasco, SP, Brazil). Foraminal patency was re-established with a \#15 K-file, and an ascending size sequence of
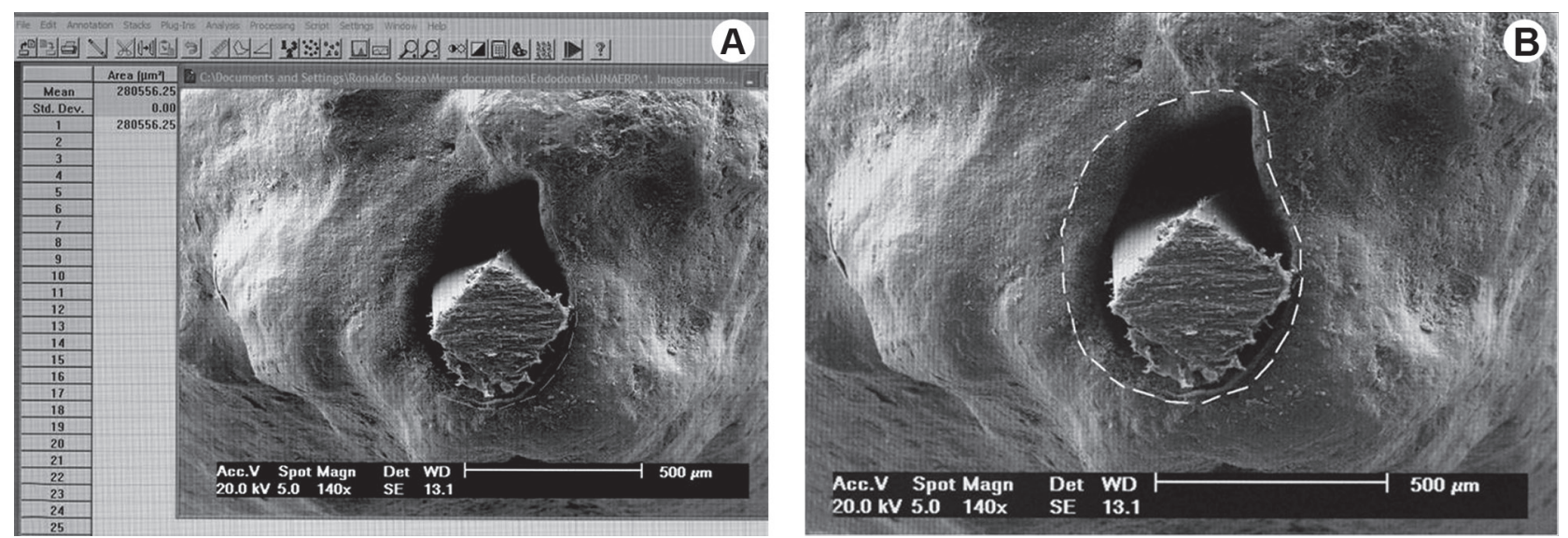

Figure 1. Measurement of the apical foramen area using the Image Tool Software. $A=$ Observe the line demarcating the foraminal area; $\mathrm{B}=$ Same image as in A seen in detail. 
presented great discrepancy in relation to the foraminal openings (Fig. 2).

Table 1 shows the mean values of the area for each apical foramen opening and file tip cross-section and the discrepancy between them $\left(\mu \mathrm{m}^{2}\right)$. As these mean values were obtained from 3 measurements for each foraminal area and 3 for each file area, Lin's Concordance Correlation Coefficient was used to verify their reproducibility. High concordance was obtained. The coefficient was superior to 0.99 in all comparisons.

Table 2 shows the mean values for file tips and apical foramina, with standard deviation, as well as the range of values and the medians. The mean area of foraminal opening was $281,341 \mu \mathrm{m}^{2}, 3.8$ times greater than the file mean area, which was $76,129 \mu \mathrm{m}^{2}$ (Table 2). Comparison of mean values by the Student's t-test demonstrated significant difference $(p<0.0001)$. The mean discrepancy between the areas of foraminal opening and file tip was $205,212 \mu \mathrm{m}^{2} \pm 80,293$.

\section{DISCUSSION}

Constriction area or CDC junction is the site where working length is ideally set $(13,14)$. It is also known as minor foramen (15). Beyond CDC junction, cemental canal diverges its walls and ends at the external root portion, the foraminal opening, where it reaches its greater diameter. For this reason, it is also known as major foramen $(13,15)$. The apical foramen is the round or circumferential extreme of the root, acting as a funnel or crater, which differentiates from the terminus of the cemental canal of the root surface (15).

Current literature demonstrates that instruments that bind at the apical constriction actually do not express
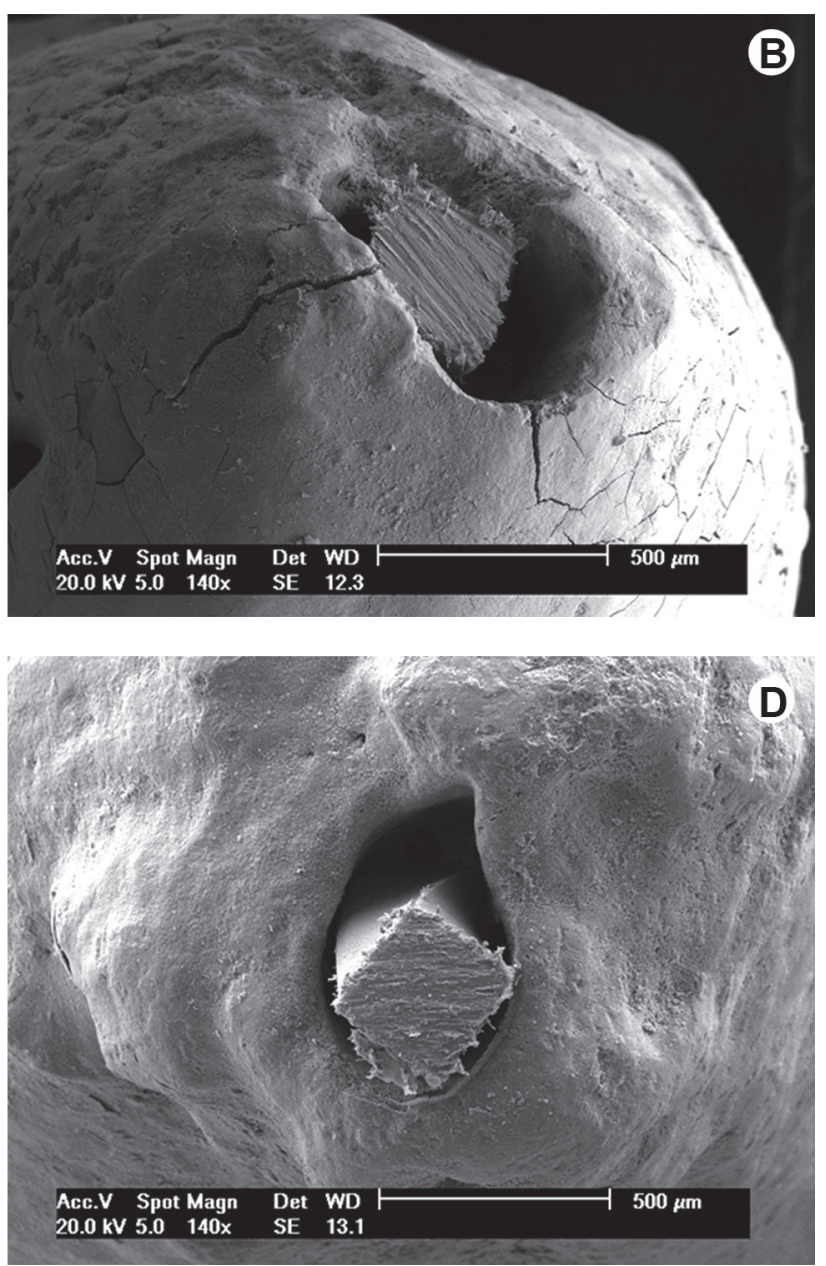

Figure 2. SEM micrographs of the files in the apical foramen. A-D = Note the great discrepancy between K-files and foramina (Original magnification $140 \times$ ). The tips of files were cut at D1 for area measurement. 
its real anatomic diameter. On the contrary, a discrepancy will exist between them (16).

If the instruments that bind at the apical constriction (minor foramen) actually show discrepancy with the convergent walls of the dentinal canal, when they reach the cemental canal there is a tendency to enhance this discrepancy because of its divergent walls, particularly at the apical foraminal opening (major foramen). This discrepancy can be observed in Figure 2 and Tables 1 and 2.

The tips of the files were cross-sectioned at D1 in this study to allow more reliable measurements. If the discrepancy was great at D1 (Fig. 2), it can be speculated that it would be even greater at D0. In the clinical condition it is the final $1 \mathrm{~mm}$ of the file that will be in the cemental canal.

Enlargement of the root canal is justified for mechanical (shaping) and biological (cleaning) reasons (17-19). The apical foramen instrumentation may be more favorable to the healing of chronic periapical lesions (20) because, exerting a mechanical action on cemental canal walls, it probably reduces bacteria load from the apical foramen and promotes a better infection control, the basis for success in Endodontics. Considering that the files that bind at the apical foramen do not touch the divergent walls of the cemental canal (Fig. 2), it is possible that infection control is not properly carried out in some cases. Therefore, apical patency does not represent an effective foraminal cleaning procedure, as assumed by some authors $(3,7,9)$, and the patency file would not remove significant amount of debris (13). According to Butler (21), the apical foramen 
should be instrumented with a file that fits closely the constriction of the canal and be followed by the next two of its type in series and size. However, as in dentinal canal, instrumentation of the cemental canal should not follow rigid pre-established principles, but rather, each clinical situation should be individually examined (22).

The results of this study suggest that it would require 4 files of greater size beyond the one that bound to the foramen in order to allow a better relationship between files and apical openings of maxillary central incisors. However, these results apply to maxillary central incisors and further research including other groups of teeth is needed.

\section{RESUMO}

Uma vez que a instrumentação do forame apical tem sido sugerida para o controle de infecção do canal radicular, este estudo analisou a relação entre as limas que se ajustam no forame apical e a abertura foraminal em cinquenta incisivos centrais superiores. Após o preparo da câmara pulpar, foi feito o acesso radicular com as brocas LA Axxess \#1 e 2 e limas K com a ponta cortada foram inseridas até que oferecessem a sensação tátil de ajuste no forame apical. Foram fixadas com cianoacrilato de metila e o conjunto dente-lima foi seccionado a $10 \mathrm{~mm}$ aquém do ápice. Foi feita a microscopia eletrônica de varredura e as áreas das limas e dos forames foram medidas por meio do Image Tool software. A análise estatística demonstrou diferença significante entre as áreas das limas e dos forames $(\mathrm{p}<0,0001)$. A média da área dos forames apicais foi 3,8 vezes maior que a das limas. Os resultados deste estudo sugerem que seriam necessários 4 instrumentos de calibre maior além do que se ajustou para que haja melhor relação entre as limas e as aberturas foraminais nos incisivos centrais superiores.

\section{REFERENCES}

1. Negishi J, Kawanami M, Ogami E. Risk analysis of failure of root canal treatment for teeth with inaccessible apical constriction. J Dent 2005;33:399-404.

2 Haapasalo M, Endal U, Zandi H, Coil JM. Eradication of endodontic infection by instrumentation and irrigation solutions. Endod Topics 2005;10:77-102.

3. Wu M-K, Dummer PMH, Wesselink PR. Consequences of and strategies to deal with residual post-treatment root canal infection. Int Endod J 2006;39:343-356.

4. Nair PNR. On the causes of persistent apical periodontitis: a review. Int Endod J 2006;39:249-281.

5. Ricucci D, Pascon EA, Ford TR, Langeland K. Epithelium and bacteria in periapical lesions. O Surg O Med O Pathol O Radiol and Endod 2006;101:239-249.
6. Buchanan LS. Management of the curved root canal. J Calif Dent Assoc 1989;17:18-25.

7. Flanders DH. Endodontic patency. How to get it. How to keep it. Why it is so important. N Y State Dent J 2002;68:9.

8. Lambrianidis T. Ledging and blockage of root canals during canal preparation: causes, recognition, prevention, management, and outcomes. Endod Topics 2009;15:56-74.

9. Lambrianidis T, Tosounidou E, Tzoanopoulou M. The effect of maintaining apical patency on periapical extrusion. J Endod 2001;27:696-698.

10. Souza RA. The importance of apical patency and cleaning of the apical foramen on root canal preparation. Braz Dent J 2006;17:6-9.

11. Hülsmann M, Schäfer E. Apical patency: fact and fiction-a myth or a must? A contribution to the discussion. Endo 2009;3:285-307.

12. Vier FV, Figueiredo JAP. Prevalence of different periapical lesions associated with human teeth and their correlation with the presence and extension of apical external root resorption. Int Endod $\mathrm{J}$ 2002;35:710-719.

13. Wu M-K, Wesselink PR, Walton RE. Apical terminus location of root canal treatment procedures. O Surg O Med O Pathol O Radiol and Endod 2000;89:99-103.

14. Lin LM, Lin J, Rosenberg PA. One-appointment endodontic therapy: biological considerations. J Am Dent Assoc 2007;138:1456-1462.

15. Vertucci FJ. Root canal morphology and its relationship to endodontic procedures. Endod Topics 2005;10:3-29.

16. Pécora JD, Capelli A, Guerisoli DMZ, Spanó JCE, Estrela C. Influence of cervical preflaring on apical file size determination. Int Endod J 2005;38:430-435.

17. Möller ÅJR, Fabricius L, Dahlén G, Sundqvist G, Happonen R-P. Apical periodontitis development and bacterial response to endodontic treatment. Experimental root canal infections in monkeys with selected bacterial strains. Eur J O Sci 2004;112:207215.

18. Fabricius L, Dahlén G, Sundqvist G, Happonen R-P, Möller ÅJR. Influence of residual bacteria on periapical tissue healing after chemomechanical treatment and root filling of experimentally infected monkey teeth. Eur J O Sci 2006;114:278-285.

19. Singla M, Aggarwal V, Logani A, Shah N. Comparative evaluation of rotary ProTaper, Profile, and conventional stepback technique on reduction in Enterococcus faecalis colony-forming units and vertical root fracture resistance of root canals. O Surg O Med O Pathol O Radiol and Endods 2010;109:e105-e110.

20. Borlina SC, Souza V, Holland R, Murata SS, Gomes-Filho JE, Dezan Junior E, et al.. Influence of apical foramen widening and sealer on the healing of chronic periapical lesions induced in dogs' teeth. O Surg O Med O Pathol O Radiol and Endod 2010;109:932940.

21. Butler NP. Apical debridement - a hypothesis and preliminary report. J Br Endod Soc 1970;4:52-56.

22. Souza RA, Figueiredo JAP, Colombo S, Dantas JCP, Lago M, Pécora JD. Location of the apical foramen and its relationship with foraminal file size. Dent Press Endod 2011;1:64-68.

Received February 23, 2011

Accepted October 1, 2011 